\title{
EVALUATION OF SPATIAL IMPLEMENTATION OF THE OPERATIONAL PROGRAMME ENVIRONMENT IN SLOVAKIA
}

\author{
[Vyhodnocení územního provádění operačního programu Životní prostředí \\ na Slovensku]
}

\author{
Oldřich Hájek ${ }^{1}$, Lenka Smékalová ${ }^{2}$, Jiří Zicha $^{3}$ \\ ${ }^{1}$ Tomas Bata university in Zlín, Faculty of Management and Economics, Mostni 5139,760 00 Zlín, Czech \\ Republic \\ Email:hajek@fame.utb.cz \\ ${ }^{2}$ Tomas Bata university in Zlin, Faculty of Management and Economics, Mostni 5139,760 00 Zlin, Czech \\ Republic \\ Email:smekalova@fame.utb.cz
2 Tomas Bata university in Zlin, Faculty of Management and Economics, Mostni 5139,760 00 Zlin, Czech Republic \\ Email:zicha@fame.utb.cz
}

\begin{abstract}
In the programming period 2007 - 2013 the implementation of the European Union cohesion policy is carried out through eleven operational programmes within the frame of objectives Convergence and Regional Competitiveness and Employment. The overall European Union resources invested the amount of approximately $€ 11 \mathrm{bn}$. in these programmes, which is distributed under the supervision of the Transport, Construction and Regional Development of the Slovak Republic (formerly only Ministry of Construction and Regional Development of the Slovak Republic). Among these instruments is the Operational Programme Environment with total allocation of $€ 1,8 \mathrm{bn}$. The objective of this paper is to analyse attributes of all projects that have been approved from the beginning of the programming period until March 2013. This will enable to further study the spatial characteristics of the evaluated programme and discuss the breakdown of the beneficiaries at different levels of spatial hierarchy or the eventual volume of intervention under auspices of this programme in individual regions of the Slovak Republic. The volume and the direction of the investments in relation to the spatial dimension present a new view on implementation of the cohesion policy instruments.
\end{abstract}

Keywords: cohesion policy, environment, Slovakia, structural funds.

JEL classification: $\mathrm{O} 18, \mathrm{O} 22, \mathrm{Q} 58, \mathrm{R} 58$

Doručeno redakci: 16.11.2013; Recenzováno: 5.5.2014; 15.5.2014; Schváleno k publikování: 23.9.2014

\section{Introduction}

In the programming period 2007 - 2013 the resources from the European Union cohesion policy present a significant part of public investments in the Slovak Republic. They are dispersed among 11 operational programmes of the Convergence and Regional Competitiveness and Employment objectives in accordance with the programming principle first introduced in late 1980s. Implementation of the cohesion policy programmes in the newer member states such as Slovakia supported significantly decentralization processes (Begg, 2010 or Bachtler and McMaster, 2007). In Slovakia this directly facilitated the emergence of the eight self-governing regions which are associated in 4 NUTS 2 regions as the Slovak Republic did not intend to adapt its public administration solely to the needs of cohesion policy (Brusis, 2005).

The architecture of Slovakian operational programmes in 2007 - 2013 programming period includes 10 programmes in the Convergence objective and 1 within the Regional 
Competitiveness and Employment objective with total allocation of approximately $€ 11 \mathrm{bn}$. of European Union resources which are continuously complemented by national and private investments. The most significant difference between the national and European regional policy lies in the spatial concentration of the resources. While the concentration of resources as stated in the National Framework of the Slovak Republic (Ministry of Transport, Construction and Regional Development of the Slovak Republic, 2007) reflects that with the exception of the Bratislava self-governing region all other are Convergence Regions. However, an indiscriminate dispersion of the EU resources would not actually comply with the concentration principle whose fulfilment has already been called to question (Crescenzi, 2009).

The regional disparities in Slovakia are subject of continuous growth since 1990s and an obvious pattern of economically stronger regions being those located in western and northwestern parts of the country disrupted only occasionally by largest settlements (Rajč́áková, Švecová, 2010). Slovakia counters these with declared concentration of cohesion policy instruments into the so called growth poles on the level of LAU 2 units (Yuill, Quiogue, 2005) that are mentioned in the National Strategic Reference Framework, too.

Delimitation of the growth poles in based mostly on the settlement structure of Slovakia as is described in the Spatial Development Perspective (Ministry of the Environment of the Slovak Republic, 2001), within this frame cohesion growth poles and innovation growth poles are distinguished. There is no detailed description of methods used in delimitating which LAU 2 units were to be growth poles, however, the criteria are stated as follows (Ministry of Transport, Construction and Regional Development of the Slovak Republic, 2007):

- information about number of inhabitants,

- information about schools,

- existence of the common municipal and registry offices,

- existence of the building authorities offices,

- general settlement structure information,

- information from the Slovak Spatial Development Perspective.

There is no indication of previous studies focused on targeting the cohesion policy resources into the growth poles, however, there are studies which research targeting the national regional policy resources and cohesion policy resources to the eight self-governing regions. Matlovič and Matlovičová (2011) conclude that national regional policy resources in decade 2001-2010 were not sufficiently targeting the less economically advanced self-governing regions, neither they targeted the most advanced region of capital city Bratislava. Structural funds measures were according to the same study marginally more successful especially in the period 2004 - 2006 when a stronger support for eastern and south-eastern self-governing regions was registered. However, the following period was less successful in these terms although it has not ended yet. Tvrdoň and Kmencová (2007) counter these findings by pointing out that easternmost regions of the Slovak Republic noted the smallest amount of support allocated from the resources of the cohesion policy.

The European Commission (2012) declared somewhat ambiguous attitude towards the Slovakian growth poles while discussing the future Partnership Agreement. While position paper does not dispute the concept of growth poles themselves the country was encouraged to evaluate the experience and possibly to change the system of growth poles delimitation which most probably reflects lack of socio-economic indicators present in their delimitation.

The Operational Programme Environment which is the main point of interest of this paper deals with questions of environment which is rather important category in terms of sustainable development which has suffered with recent strains placed on public budgets (Darvas, 2010) a situation which even further emphasized the importance of cohesion policy available resources. It is one of the largest operational programmes which reflects the importance of 
environmental pillar which is emphasized even on the European level. The Europe 2020 strategy has strongly promoted the issues of environment and set targets of reducing green gas emissions, increase in use of renewable energies and increase in energetic efficiency. The ability to fulfil the abovementioned goals has already been widely discussed see e.g. (Oberthür and Roche Kelley, 2008; Saikku et al., 2008; Böhringer et al., 2010 discussing the greenhouse gasses or Klessmann et al. (2010), da Graça Carvalho (2012) researching the energy sector implication while Warleigh-Lack (2010) discussed the strategy in its environmental implication as the means of delivering quality public policy.

This paper aims to analyse the implementation of the Operational Programme Environment with regard to spatial characteristics of allocation dispersion which. This will enable further the discussion about support of growth poles and thematic interventions in individual regions thus presenting a new view of cohesion policy instruments in practice.

\section{Methodology of the Paper}

The basis data for the following analysis of the Operational Programme Environment are taken from the Central coordination Body of the Slovakia which publishes the list of beneficiaries of all operational programmes. This list detailing the projects as of $30^{\text {th }}$ April 2013 provided the initial projects' matrix including information about beneficiaries (name and identification number), projects (project codes and partial titles of projects) and the individual budgets - Union contribution, national budget resources and private contribution as specified in grant contracts. All 655 projects which were listed as of the above-mentioned date are subject of the analysis. The only exception are technical assistance projects. This amount of projects represents 98,6\% of the total allocation of the Operational Programme Environment in the period 2007-2013 and as such provides sufficient data for analysis.

The information in the initial officially published matrix, so far insufficient, was later enhanced by detailed description of beneficiaries obtained from the Statistical registry of organizations maintained by the Statistic Office of the Slovak Republic. The registry provided information about SK-NACE category, beneficiary size in terms of number of employees, the institutional sector and location of the beneficiary within the administrative structure of the Slovak Republic.

Information about projects was expanded by decomposing the unique project codes which enabled the authors to identify the specific priority axes and measures whose resources were used in project implementation. However, the question of location of projects remained. The necessary information is included in every grant contract and the contract database, a registry Central Register of Contracts, is maintained by the Government Office of the Slovak Republic.

Table 1: Sources of information in matrix of projects

\begin{tabular}{|l|l|}
\hline \multicolumn{1}{|c|}{ Attribute } & \multicolumn{1}{c|}{ Information source } \\
\hline Project title and ID & $\begin{array}{l}\text { List of beneficiaries } \\
\text { published by Central } \\
\text { coordination body }\end{array}$ \\
\cline { 1 - 2 } Beneficiary title and code & Statistic Office of the \\
Project budget & Slovak Republic \\
\hline SK-NACE of the beneficiary & $\begin{array}{l}\text { Central register of } \\
\text { Number of employees of the beneficiary } \\
\text { Government Office of } \\
\text { Slovak republic }\end{array}$ \\
\hline Institutional sector of the beneficiary & \\
\cline { 1 - 2 } Location of the beneficiary &
\end{tabular}

Source: Authors

After obtaining the necessary information about the project the matrix has been complemented by information whether or not the location of both beneficiary and project 
realization belonged among the growth poles of Slovakia. The total amounts of investment spent were recalculated per capita both in case of the beneficiary location and in case of project site location at the level of the Regions (NUTS III) and the districts (LAU 1). The matrix has then been evaluated by the methods of descriptive statistics, mainly by means of cross tabulation. The spatial dispersion of EU support per capita was depicted using the ArcGIS software at the level of districts.

\section{Results and Discussion}

The evaluation of the implementation of the Operational programme Environment is conducted with matrix of 655 approved projects in mind. These were approved of in period 2007 - 31th March 2013 within 54 separately issued calls for proposals within seven priority axes (see table 2). The calls for proposals were directed to unspecified beneficiaries as well as to specifically chosen beneficiaries in cases of so called national projects whose location within the administrative structure of the Slovakia was undisclosed or covered the entire country. So far no projects have been implemented under the priority axis "Building a Flood Warning and Forecasting System" which was newly added to the third version of programme document validated by the European Commission in June 2011. Within the other priority axes grant contracts amounting to $€ 1743$ mil. were concluded with further $€ 175$ mil. of private co-funding. In relation to the initial allocation of the Operational Programme Environment this constitutes approximately 96,8 \% of total allocation from both European Cohesion Fund and European Fund for Regional Development which finance the programme and as such the authors perceive this amount as sufficient base for analysis. As it is showed in table 3 the Operational Programme Environment does not significantly limit the spatial location of the beneficiaries especially in its most prominent priority axes. This goes hand in hand with dismissing the idea of preferential treatment of the growth poles as the environmental problems are hardly limited by administrative borders of any kind.

Table 2: Financial share of priority axes on European, national and private resources in approved projects (€ mil.)

\begin{tabular}{|l|r|r|r|}
\hline \multicolumn{1}{|c|}{ Priority axis } & EU allocation & Slovak Republic Allocation & Co-funding \\
\hline Integrated Protection and Rational Utilisation of Water & 838,10 & 130,05 & 49,72 \\
\hline Flood Protection & 84,02 & 12,60 & 5,09 \\
\hline $\begin{array}{l}\text { Air Protection and Minimisation of Adverse Effects of Climate } \\
\text { Change }\end{array}$ & 147,98 & 21,27 & 44,59 \\
\hline Waste Management & 357,14 & 48,48 & 76,30 \\
\hline Protection and Regeneration of Natural Environment and Landscape & 42,79 & 7,55 & 0 \\
\hline Technical Assistance & 45,25 & 7,99 & 0 \\
\hline Building a Flood Warning and Forecasting System & 0 & 0 & 0 \\
\hline Total & 1515,28 & 227,93 & 175,70 \\
\hline
\end{tabular}

Source: Authors' calculations based on list of beneficiaries

Table 3: Limitations of potential beneficiaries

\begin{tabular}{|c|c|c|}
\hline Priority axis & Spatial limitation & Beneficiary limitation \\
\hline $\begin{array}{l}\text { Integrated Protection and Rational Utilisation of } \\
\text { Water }\end{array}$ & No limitations & No significant limitation \\
\hline Flood Protection & No limitations & Municipalities, waterway management \\
\hline $\begin{array}{l}\text { Air Protection and Minimisation of Adverse Effects } \\
\text { of Climate Change }\end{array}$ & $\begin{array}{r}\text { Convergence objective } \\
\text { regions }\end{array}$ & No significant limitation \\
\hline Waste Management & No limitations & No significant limitation \\
\hline $\begin{array}{l}\text { Protection and Regeneration of Natural } \\
\text { Environment and Landscape }\end{array}$ & $\begin{array}{r}\text { Convergence objective } \\
\text { regions }\end{array}$ & $\begin{array}{r}\text { Selected central government } \\
\text { institutions }\end{array}$ \\
\hline Technical Assistance & 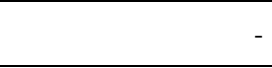 & $\begin{array}{r}\text { Managing authority, intermediate } \\
\text { bodies }\end{array}$ \\
\hline Building a Flood Warning and Forecasting System & $\begin{array}{r}\text { Convergence objective } \\
\text { regions }\end{array}$ & Slovak Hydro-meteorological Institute \\
\hline
\end{tabular}

Source: Programme Document and Programme Manual of Operational Programme Environment 
Relatively less strict restriction of beneficiary profile within the Operational Programme Environment is reflected in high share of private sector beneficiaries visible in table 4 . The support is still predominately aimed at the public sector which is caused mainly by notable activity of the cities, municipalities and associations of these public sector subjects. The central government is represented by state owned corporations and public institutions involved in water management and environmental protection.

The activities of central government subjects were restricted almost exclusively to Bratislava and Banská Bystrica Regions as these are the main seat of environment related governmental agencies. The activities of local government were dispersed more evenly through the regions with their activity peaking in Trnava and Prešov Regions. The private beneficiaries are especially successful in central Slovakia regions - Nitra, Trenčín, Žilina and Banská Bystrica. In some of them (e. g. Žilina) they partially make up for the inactivity of local government.

Table 4: Share of EU allocation among institutional sectors from approved projects

\begin{tabular}{|l|r|}
\hline \multicolumn{1}{|c|}{ Institutional sector } & Share of EU allocation \\
\hline Private subjects & $45,45 \%$ \\
\hline Central government subjects & $9,50 \%$ \\
\hline Local government subjects & $45,04 \%$ \\
\hline
\end{tabular}

Source: Authors' calculations based on list of beneficiaries

Out of the entire Operational Programme Environment allocation that has been apportioned to the approved projects from the European Union resources 45,45 \% (approximately $€ 688$ mil.) was dealt to the private sector (refer to table 4 for shares of individual sectors). This amount was distributed among differently sized enterprises with the largest share of medium-sized enterprises ( $37 \%$ which corresponds to $€ 255 \mathrm{mil}$.), followed by large-sized enterprises $(28 \%)$. The share of small enterprises is $23 \%$ and micro enterprises supported amounted to $12 \%$. In terms of spatial distribution the small and medium enterprise support per capita is most notable in group of three central Slovakian regions Žilina ( $€ 231$ per inhabitant), Trenčín ( $€ 185$ per inhabitant) and Banská Bystrica ( $€ 108$ per inhabitant).

The prevalent thematic focus of all beneficiaries regardless the institutional sector or the enterprise size is the environmental infrastructure (see table 5). This topic is rarely complemented by projects focused on transport infrastructure and services which are mostly concerned with acquiring newer vehicles more friendly to the environment. The share of human resources oriented projects is altogether marginal. Within the public sector smallersized institutions are somewhat more successful applicants with more than three quarters of allocation dealt to public sector.

Table 5: Share of EU allocation among institutional sectors from approved projects

\begin{tabular}{|c|c|c|c|c|c|c|c|c|c|c|}
\hline \multirow{2}{*}{$\begin{array}{l}\text { Thematic focus } \\
\text { of the projects }\end{array}$} & \multirow{2}{*}{$\begin{array}{l}\text { Total } \\
\text { share }\end{array}$} & \multicolumn{5}{|c|}{ Beneficiary size - private sector } & \multicolumn{4}{|c|}{ Beneficiary size - public sector } \\
\hline & & $1 *$ & 2 & 3 & 4 & 5 & 1 & 2 & 3 & 4 \\
\hline $\begin{array}{l}\text { Human } \\
\text { Resources } \\
\text { Development }\end{array}$ & $2,38 \%$ & $0 \%$ & $0 \%$ & $1,65 \%$ & $6,25 \%$ & $0 \%$ & $0,00 \%$ & $3,22 \%$ & $0,16 \%$ & $0,00 \%$ \\
\hline $\begin{array}{l}\text { Transport } \\
\text { Infrastructure } \\
\text { and Services }\end{array}$ & $0,59 \%$ & $0 \%$ & $2,40 \%$ & $0,10 \%$ & $0 \%$ & $0 \%$ & $0,00 \%$ & $0,00 \%$ & $0,69 \%$ & $7,58 \%$ \\
\hline $\begin{array}{l}\text { Environmental } \\
\text { Infrastructure }\end{array}$ & $97,02 \%$ & $100 \%$ & $97,60 \%$ & $98,25 \%$ & $93,75 \%$ & $\begin{array}{r}100 \\
\%\end{array}$ & $100,00 \%$ & $96,78 \%$ & $99,15 \%$ & $92,42 \%$ \\
\hline
\end{tabular}

*1 - Micro enterprise, 2 - Small enterprise, 3 - Medium-sized enterprise, 4 - Large-sized enterprise, 5 -

Unknown size of enterprise

Source: Authors' calculations based on list of beneficiaries 
The spatial point of view of the allocation dispersion within the Operational Programme Environment is strongly influenced by existence of so called national projects. These are numerous projects whose exact place of location at the level of LAU 2 - municipality is not detailed in the grant contract in accordance with the thesis that the environmental issues are hardly restricted by administrative boundaries. It is equally improbable that most of the national projects would deal with issues limited by a single municipality therefore the scope of these projects is much larger sized to the area of several self-governing regions or indeed the entire Slovak Republic.

Further analysis of spatial characteristics, as they pertain to sector, location and size of the beneficiary, revealed interesting fact which is connected to relationship between seat of the beneficiary and the project realization site. It is quite possible to estimate that local government institutions implement the projects within their own boundaries. In this particular data set $96 \%$ of local governments obtained resources were spent within the boundaries of their own district. The case of central governmental agencies is quite the opposite as $82 \%$ of obtained allocation is spent outside of the district in which they are located due to their wide territorial scope. However, an interesting difference occurs between the group of large and the group of small and medium enterprises. Curiously enough the large enterprises invested more obtained resources $(83 \%)$ within their residential districts than small and medium enterprises $(67 \%)$. These findings are, of course, a product of rather limited and narrowly oriented data set, especially thematic-wise. Their further evaluation on a larger sample may, however, lead to more definite knowledge concerning the influence of the private enterprise size on distribution of allocated amount in space and its relation to corporate headquarters location.

Table 6: Financial resources allocated to supported and other regions

\begin{tabular}{|l|r|r|}
\hline \multirow{2}{*}{ Types of Regions } & \multicolumn{2}{|c|}{ Financial support by the European Union per inhabitant (units: $€$ ) } \\
\cline { 2 - 3 } & According to the beneficiary location & According to the project site location \\
\hline Growth Poles & 311 & 259 \\
\hline -cohesion growth poles & 209 & 315 \\
\hline -innovation growth poles & 382 & 220 \\
\hline $\begin{array}{l}\text { Municipalities which are not } \\
\text { growth poles }\end{array}$ & 83 & 234 \\
\hline
\end{tabular}

Source: Authors' calculations based on list of beneficiaries

Even though tables 6 and 7 indicate that the beneficiaries are located predominantly in those municipalities that are located higher in the settlement hierarchy of the Slovak Republic and at the same time are also innovation growth poles. However, activities of these beneficiaries are not limited by boundaries of their own municipalities rather the implementation of quite a few of these projects takes place outside in smaller municipalities including those that are not designated as growth poles which is indeed quite rare in the Slovak operational programmes as most of them target growth poles preferentially to other municipalities.

Table 7: Allocation of EU financial resources with regards to hierarchy of Slovak settlements

\begin{tabular}{|c|c|c|}
\hline \multirow{2}{*}{$\begin{array}{l}\text { Municipality categories according to } \\
\text { population }\end{array}$} & \multicolumn{2}{|c|}{ Financial support by the European Union per inhabitant (units: $€$ ) } \\
\hline & According to the beneficiary location & According to the project site location \\
\hline Bratislava and Košice municipalities & 267 & 99 \\
\hline More than 50 thousand inhabitants & 581 & 119 \\
\hline $20-50$ thousand inhabitants & 241 & 172 \\
\hline $5-20$ thousand inhabitants & 364 & 453 \\
\hline Less than 5 thousand inhabitants & 146 & 270 \\
\hline
\end{tabular}

Source: Authors' calculations based on list of beneficiaries

The overall spatial dispersion of the EU support is shown in figures 1 and 2 which depict allocation per capita from the point of view of the beneficiaries and project site location, respectively. The allocation at the level of Slovakian districts, which are equivalent of the LAU 1 units, is strongly influenced by the location of governmental agencies as far as the 
beneficiary oriented point of view goes. The most prominent district of Banská Štiavnica in Banská Bystrica Region is the seat of Slovak Water-management Authority which gives this region considerable advantage from the point of view of the beneficiaries, even more pronounced considering the relatively smaller number of inhabitants if compared to other regions where central government agencies are located. The location sites of the projects obtained by the Slovak Water-management Authority are spread evenly through the country, though, many of them having regional rather than local character. Thus its existence has almost no bearing on position of the Banská Bystrica district in figure 2 .

Figure 1: Spatial dispersion of the Operational Programme Environment resources with regards to the location of the beneficiaries

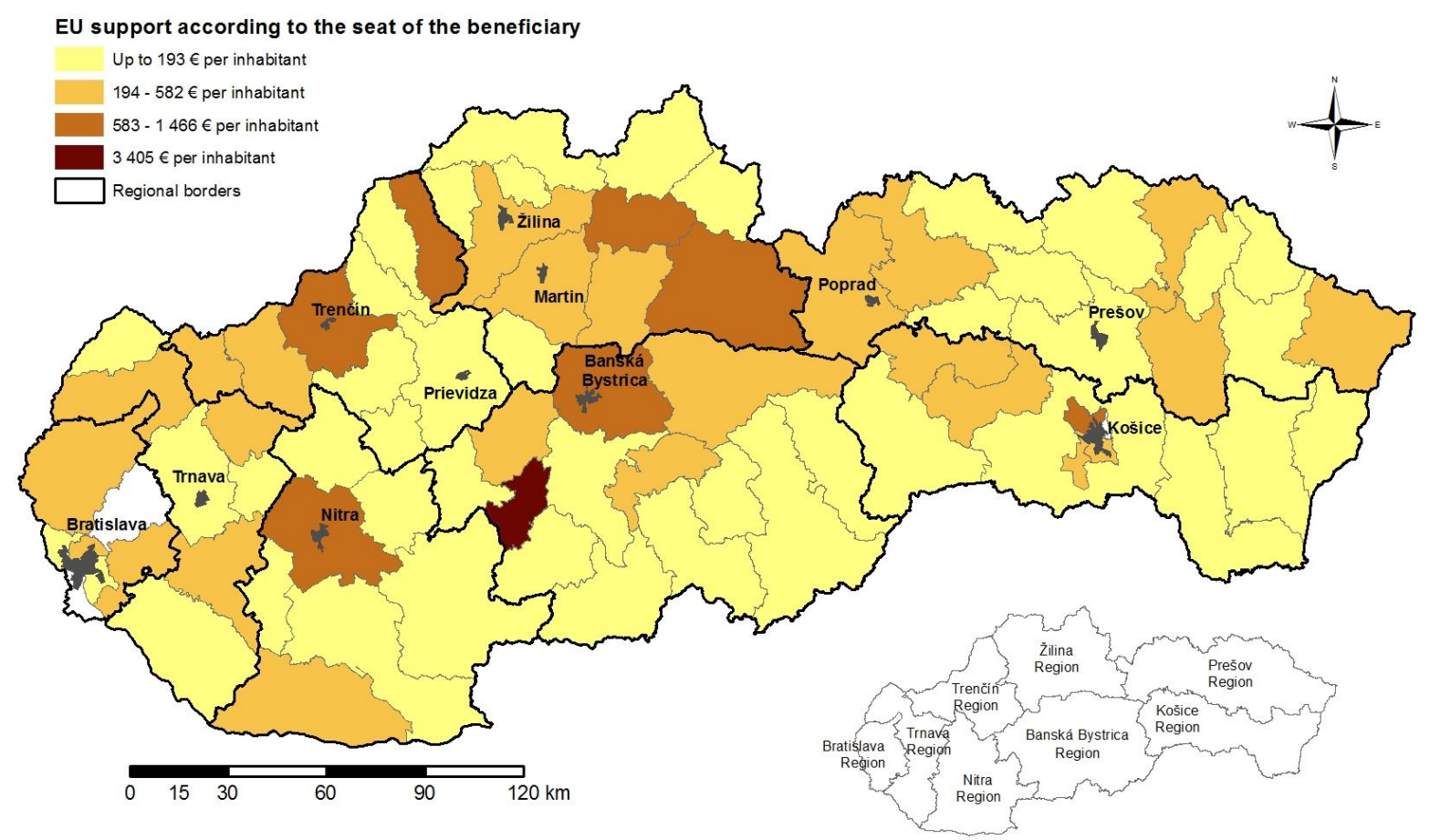

Source: Authors' calculations based on list of beneficiaries by the Central Coordination Body

The spatial dimension of EU support pertaining to project localization sites as depicted in figure 2 shows somewhat different state of affairs. The most prominently featured districts are often those whose areas coincide with areas of national parks. This is particular for district of central Slovakia and some of the Eastern districts. When the allocation is decomposed according to the individual priority axes of the Operational Programme Environment the prominence of these regions is maintained through several of them but especially in "Protection and Regeneration of Natural Environment and Landscape" axis. "Integrated Protection and Rational Utilisation of Water" axis support is rather equally distributed among the districts with the exception of the largest cities district of Bratislava and Košice and some of the southern and North-eastern districts. However, those are partially compensated by their prominence in priority axis "Flood Protection" whose largest projects target especially protection of smaller towns up to 5 thousand inhabitants which are not likely to be able to make such investments by themselves considering their budgets. Priority axis "Air Protection and Minimisation of Adverse Effects of Climate Change" shows relatively equal dispersion with the exception of Bratislava Region and southern district of Nitra and Banská Bystrica Regions. "Waste Management" priority axis project concentrate especially in Eastern Slovakia districts. 
The overall dispersion of projects according to the site of realization shows some white places in Bratislava Region which are particularly interesting as there is no compensation for this lack of environmentally oriented projects in the regionally specific Operational Programme Bratislava Region.

Figure 2: Spatial dispersion of the Operational Programme Environment resources with regards to the size of project implementation

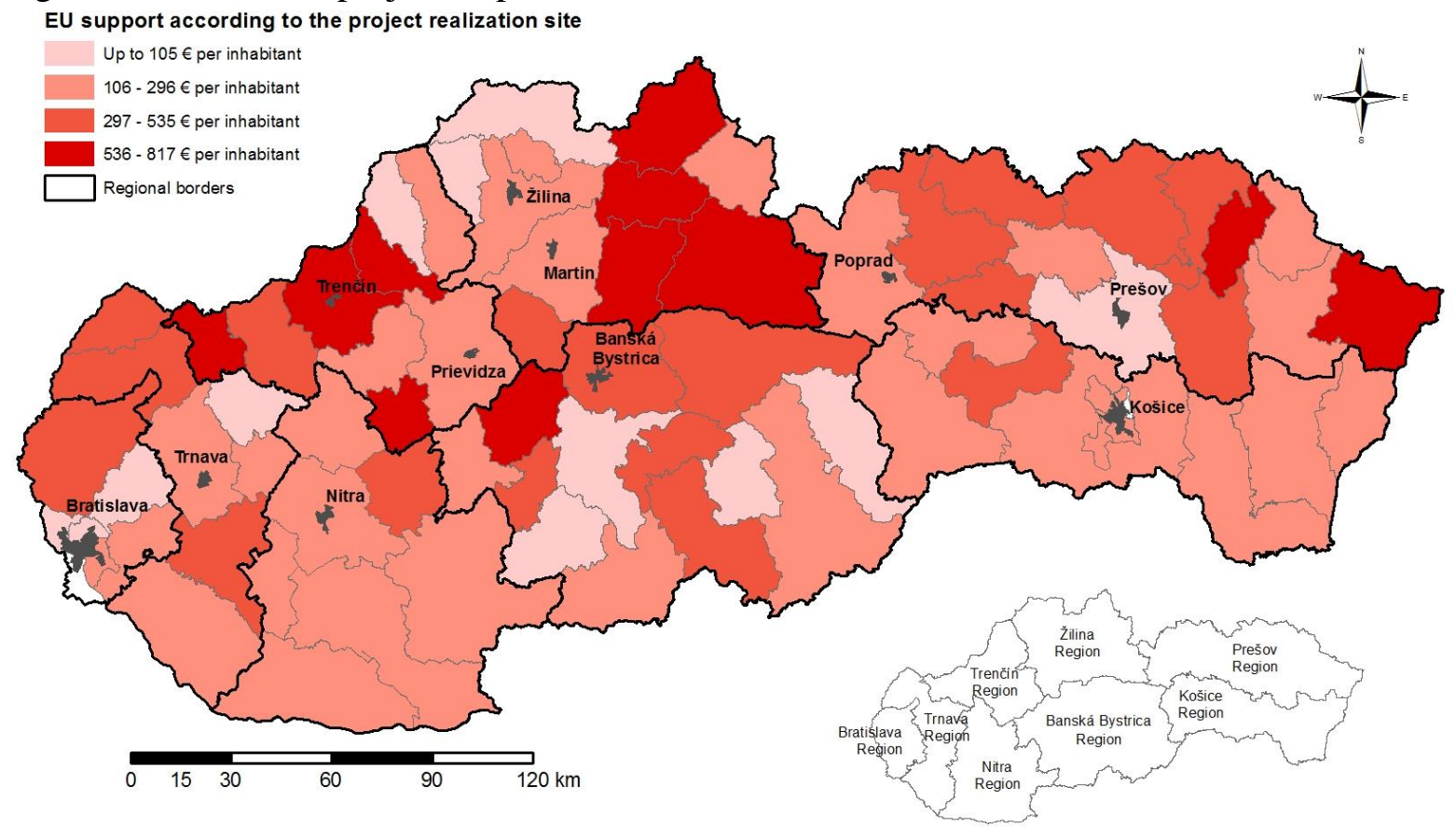

Source: Authors' calculations based on list of beneficiaries by the Central Coordination Body

\section{Conclusion}

Operational programme Environment was allocated $€ 1,8 \mathrm{bn}$. making it one of the most prominent financial instruments of the cohesion policy programming period $2007-2013$ within the Slovak Republic. The aim of this paper was to provide the analysis of the implemented projects under the programme. In accordance with the thematic focus the projects were mainly targeting issues of the environmental protection with special focus on water management which is apart from its own priority axis common focus of most suggested areas of intervention. However, there is a priority axis connected to water management "Building a Flood Warning and Forecasting System" which recorded no implemented project in the researched period. Due to broader consequences of the environmental issues this operational programme does not accentuate the spatial areas of growth poles innovation or otherwise.

The basis for the analysis was created by the studied matrix of 655 projects that were approved of and taken under individual grant contracts within the scope of 54 announced calls for proposals from the beginning of the programme implementation. The total allocation amassed by the evaluated projects is $€ 1743$ mil. and $€ 175$ mil. more were supplied by cofunding. This amounts to $96,8 \%$ of European Union commitment within both Cohesion Fund and European Regional Development Fund.

The spatial point of view yielded some interesting observation such as identification of beneficiaries who are mainly concentrated in larger cities, e. g. respective capitals of the selfgoverning regions. These are usually seats of the public sector institutions which are among preselected beneficiary types. From the point of view of implementation site the mediumsized cities up to 20000 inhabitants actually profit from project implementation within their 
boundaries and the smaller towns up to 5 thousand inhabitants benefit from realization of large projects which their own budgets could not support.

An interesting result was obtained when analysing dispersion of funds among private enterprises in relation to the headquarters location. The large corporations, in this particular operational programme, tend to invest the money in their residential district more often than the small and medium enterprises. While this finding is certainly influenced by the narrow focus of analysed data, at the same time, it presents an interesting question for future research focused either on a more broad scope of operational programmes or on specific operational programmes which target private corporations specifically.

The recommendation stemming from the above-mentioned findings can be aimed especially in terms of more deliberate and sober preparation of the following programming period. The precise and clear listing of the needs of the Slovak Republic should be as timely as possible. It is clear that the late significant addition to the list of programme axes led to a lesser utilization of allocated amount of EU support. The exclusion of Bratislava Region is another instance which should be reconsidered as it was already noted that the environmental issues are not limited by administrative borders. The problems of Bratislava Region which belongs among the economically more advanced NUTS II of the European Union should be addressed either in environment specific or in region specific operational programme. The advance of Bratislava Regions as it is recorded in economic field may very well be accompanied by a set of environmental issues specific to this region. At the lower municipal level the disregard for state determined areas of support can be seen as positive in case of this operational programme and is desirable for the following period, too.

Considering the allocation of the Operational Programme Environment is almost spent, since $98,6 \%$ are already under grant contracts, this programme can be regarded as a successful financial instrument. The positive experience gained from the implementation of the Operational Programme Environment should provide a suitable starting point for implementation of new operational programmes in 2014 - 2020 programming period.

\section{Acknowledgement}

The authors are thankful to the Operational Programme Education for Competitiveness cofunded by the European Social Fund (ESF) and national budget of the Czech Republic for the grant No. CZ.1.07/2.3.00/20.0147 - "Human Resources Development in the field of Measurement and Management of Companies, Clusters and Regions Performance", which provided financial support for this research.

\section{References}

[1] BACHTLER, J. F. and I. MCMASTER, 2007. EU Cohesion Policy \& the Role of the Regions: Investigating the Influence of Structural Funds in the New Member States. Environment and Planning C: Government and Policy, 26(2), 398-427. ISSN 1472-3425.

[2] BEGG, I., 2010. Cohesion or Confusion: A Policy Searching for Objectives. Journal of European Integration, 32(1), 77-96. ISSN 0703-6337.

[3] BÖHRINGER, C., T. F. RUTHERFORD and R. S. TOL, 2009. The EU 20/20/2020 targets: An overview of the EMF22 assessment. Energy Economics, 31(2), 268-273. ISSN 0140-9883.

[4] BRUSIS, M., 2005. The Instrumental Use of European Union Conditionality: Regionalization in the Czech Republic and Slovakia. East European Politics and Societies, 19(2), 291-316. ISSN 0888-3254. 
[5] CRESCENZI, R., 2009. Undermining the Principle of Concentration? European Union Regional Policy and the Socio-Economic Disadvantage of European Regions. Regional Studies, 43(1), 111-133. ISSN 0034-3404.

[6] DA GRAÇA CARVALHO, M., 2012. EU energy and climate change strategy. Energy, 40(1), 19-22. ISSN 0360-5442.

[7] DARVAS, Z., 2010. The Impact of the Crisis on Budget Policy in Central and Eastern Europe. OECD Journal on Budgeting, 10(1), 1-42. ISSN 1608-7143.

[8] EUROPEAN COMMISSION, 2012. Position of the Commission Services on the development of the Partnership Agreement and programmes in SLOVAKIA for the period 2014-2020 [online]. [cit. 20th October 2013]. Accessible from: http://ec.europa.eu/regional_policy/what/future/pdf/partnership/sk_position_paper.pdf

[9] KLESSMANN, C., A. HELD, M. RATHMANN and M. RAGWITZ, 2011. Status and perspectives of renewable energy policy and deployment in the European Union - What is needed to reach the 2020 targets? Energy policy, 39(12), 7637-7657. ISSN 0301-4215.

[10] MATLOVIČ, R. a K. MATLOVIČOVÁ, 2011. Regionálne disparity a ich riešenie na Slovensku v rozličných kontextoch. Acta Facultatis Studiorum Humanitatis et Naturae Universitatis Prešoviensis, Folia Geographica, 53(18), 8-87. ISSN 1336-6157.

[11] MINISTRY OF THE ENVIRONMENT OF THE SLOVAK REPUBLIC, 2001. Koncepcia územného rozvoja Slovenska (Slovak Spatial Development Perspective) [online]. [cit. 28th October 2013]. Accessible from: http://www.telecom.gov.sk/index/open_file.php?file=vystavba/StatStavSpravaDokument y/UzemnePlanovanie/KoncepUzemRozvojaSK/ZavaznaCast/kurs2001.PDF

[12] MINISTRY OF TRANSPORT, CONSTRUCTION AND REGIONAL DEVELOPMENT OF THE SLOVAK REPUBLIC, 2007. Národný strategický referenčný rámec 2007 - 2013 [online]. [cit. 28th October 2013]. Accessible from: http://www.nsrr.sk/download.php?FNAME=1381926411.upl\&ANAME=NSRR+0713+april+2013.zip

[13] OBERTHÜR, S. and C. ROCHE KELLY, 2008. EU leadership in international climate policy: achievements and challenges. The International Spectator, 43(3), 35-50. ISSN 0393-2729.

[14] RAJČÁKOVÁ, E. and A. ŠVECOVÁ, 2010. Regional Disparities in The Context Of Slovak Regional Policy. In: V. KLÍMOVÁ, ed. XII. mezinárodni kolokvium o regionálních védách. Brno: Masarykova univerzita, s. 34-41. ISBN 978-80-210-5210-9

[15] SAIKKU, L., A. RAUTIAINEN and P. E. KAUPPI, 2008. The sustainability challenge of meeting carbon dioxide targets in Europe by 2020. Energy Policy, 36(2), 730-742. ISSN 0301-4215.

[16] TVRDOŇ, J. a Z. KMECOVÁ, 2007 Implikácia regionálne disparity vs. Absorpčná schopnost'. In: Národná a regionálna ekonomika VI. Košice: Ekonomická fakulta TU v Košiciach.

[17] WARLEIGH-LACK, A., 2010. Greening the European Union for legitimacy? A cautionary reading of Europe 2020. Innovation-The European Journal of Social Science Research, 23(4), 297-311. ISSN 1351-1610.

[18] YUILL, D. and N. C. QUIOGUE, 2005. Spatial Targeting under EU and National Regional Policies. In: Benchmarking Regional Policy in Europe. Glasgow: European Policies Research Centre, s. 1-29. 